\title{
IAMJ
}

INTERNATIONAL

AYURVEDIC

MEDICAL JOURNAL

Case Report

ISSN: 2320-5091

Impact Factor: 6.719

\section{ROTATOR CUFF TENDON INJURY - AN AYURVEDA MANAGEMENT WITH JALOUKAVACARANA}

\author{
Bhavya K.G' ${ }^{\text {, George M.J. }}{ }^{2}$ \\ ${ }^{1} \mathrm{PG}$ scholar, ${ }^{2}$ Professor and H.O.D. \\ Dept. of Shalya tantra, VPSV Ayurveda College, Kottakkal, Kerala, India
}

Corresponding Author: kgbhavya98@gmail.com

https://doi.org/10.46607/iamj2309062021

(Published Online: June 2021)

Open Access

(C) International Ayurvedic Medical Journal, India 2021

Article Received: 13/05/2021 - Peer Reviewed: 02/06/2021 - Accepted for Publication: 04/06/2021

Check for updates

\begin{abstract}
Most shoulder pain is related to muscle or tendon strain. Chronic pain is often triggered by prior injuries, especially if original injury was severe or was not allowed to heal completely. Shoulder injury can cause weakness, tenderness and loss of full joint mobility. More common and less traumatic causes include lifting, reaching and pulling movements that strain the muscles and tendons or sprain ligaments surrounding the shoulder joint. Injury may or may not be realized during the activity. Various conditions like shoulder joint impingement, frozen shoulder, and rotator cuff tendinitis have resembling symptoms under the umbrella of disease Avabahuka described in Ayurveda. Leech application was carried out in first stage where there is reduced vascular supply. Here a case report of a female aged 31years old, who had an acute on chronic rotator cuff strain from strenuous activity underwent three sittings of Jaloukavacarana.
\end{abstract}

Keywords: Rotator cuff tendon injury, Avabahuka, Jaloukavacarana.

\section{INTRODUCTION}

Disorder of rotator accounts for almost $50 \%$ of major shoulder injuries but are sometimes difficult to diagnose. ${ }^{1}$ This is sometimes referred as the 'rotator cuff syndrome'. Patients with rotator cuff tendinitis have pain and weakness on active abduction and those with a severe tear of the cuff are unable to initiate abduction. They may be able to hold the arm abducted once it has been raised by the examiner. If there is weakness with 
some movements but not with others, then one must rule out a partial or complete tendon rupture. The clinical examination must include number of provocative tests to determine the source of patient's symptoms. ${ }^{2}$ The average thickness of the normal tendon of the rotator cuff is $10-12 \mathrm{~mm}^{3}$.Partial thickness tear occurs within the tendon and do not communicate with the sub acromial bursa or the glenohumeral joint. The incidence of partial tears is unclear, because most, especially intratendinous lesions, can only be identified by operations, and MRI may demonstrate partial tears in asymptomatic individuals. ${ }^{3}$ The natural history and progression of rotator cuff disease from simple tendinitis to partial- and full-thickness rotator cuff tears remain poorly understood and are an area of considerable debate. $^{4}$

\section{CASE REPORT}

A 31-year-old female visited Shalya Tantra OPD with left shoulder pain and restricted movements. She had a history of fall with hyperflexed abducted shoulder in washroom two days back. She was taking internal medication previously for recurrent shoulder joint pain. There was no other associated systemic illness. On detailed examination no associated neurological deficits were seen. The findings are given in table 1 and table 2.

Table 1:

\begin{tabular}{|l|l|}
\hline ROM & Goniometric assessment \\
\hline Abduction & $40^{\circ}$ (Goniometric assessment) \\
\hline Adduction & Complete \\
\hline Flexion & $60^{\circ}$ \\
\hline Extension & Painful \\
\hline External rotation on abduction & Painful \\
\hline Internal rotation on abduction & Possible \\
\hline Medial rotation & Painful \\
\hline Lateral rotation & Possible \\
\hline
\end{tabular}

The condition was provisionally diagnosed on examination as acute rotator cuff tendon injury. An $\mathrm{x}$ ray was taken which revealed no bone injury.

Table 2:

\begin{tabular}{|l|l|}
\hline VAS for pain & 9 \\
\hline Drop arm sign & Positive \\
\hline Empty can sign & Positive \\
\hline
\end{tabular}

The patient was given a figure-of-eight shoulder bandage (Swastika bandhana) and pouch arm sling for immobilisation from the OP level along with internal medications and Murivenna pichu (cotton pad with medicated oil). After a week she got an MRI done and re-visited for IP management. The MRI revealed a small full thickness tear of distal fibres of supraspinatus tendon. (Table 3)

\section{Table 3:}

MRI Impression

Small full thickness tear of distal fibers of supraspinatus tendon.

Mild degenerative changes in form of erosions are noted involving greater and lesser tubercle.

Mild subscapularis tendinosis is seen.

Fluid is seen in the sub acromial bursa.

Mild joint effusion is seen.

Coracohumeral interval is only $5 \mathrm{~mm}$. 


\section{TREATMENT}

Table 4:

\begin{tabular}{|c|c|c|}
\hline OP MANAGEMENT & $\begin{array}{l}\text { Shoulder bandage with } \\
\text { Alepana (medicated mask) } \\
\text { Murivenna pichu } \\
\text { Laksha guggulu 1tid }\end{array}$ & $\begin{array}{l}\text { Pain VAS-9 } \\
\text { ROM - painful active abduction } 20\end{array}$ \\
\hline \multicolumn{3}{|l|}{ IP MANAGEMENT } \\
\hline Day 1 & $\begin{array}{l}\text { Jaloukavacarana (leech } \\
\text { therapy) } \\
\text { Immobilization* } \\
\text { Murivenna pichu }\end{array}$ & $\begin{array}{l}\text { Pain VAS - } 7 \\
\text { ROM - painful active abduction } 40^{\circ}\end{array}$ \\
\hline Day $2,3,4$ & $\begin{array}{l}\text { Immobilization } \\
\text { Murivenna pichu } \\
\text { Nagaradi lepam }\end{array}$ & Pain VAS - 6 \\
\hline Day 5 & $\begin{array}{l}\text { Jaloukavacarana } \\
\text { Immobilization }\end{array}$ & Pain VAS - 3 \\
\hline Day 6,7 & $\begin{array}{l}\text { Immobilization } \\
\text { Murivenna pichu } \\
\text { Nagaradi lepam }\end{array}$ & Pain VAS -3 \\
\hline Day 8 & $\begin{array}{l}\text { Jaloukavacarana } \\
\text { Partial immobilization** }\end{array}$ & $\begin{array}{l}\text { Pain VAS }-2 \\
\text { ROM - painful active abduction } 90^{\circ}\end{array}$ \\
\hline Day $9-14$ & $\begin{array}{l}\text { Upanaham (medicated } \\
\text { bandage) with Upanaha } \\
\text { choornam } \\
\text { and Vatahara patra } \\
\text { Partial immobilization }\end{array}$ & $\begin{array}{l}\text { Pain VAS }-1 \\
\text { ROM - Painful active abduction } 110^{\circ} \text { on } 14^{\text {th }} \text { day }\end{array}$ \\
\hline Day 15- 21 & $\begin{array}{l}\text { Shastika shaali lepam } \\
\text { Partial immobilization }\end{array}$ & $\begin{array}{l}\text { Pain VAS - } 0 \\
\text { ROM - Painless active abduction } 120^{\circ} \text { on } 21^{\text {st }} \text { day }\end{array}$ \\
\hline Day $22-27$ & Static exercises & ROM- Painless active abduction $140^{\circ}$ on $27^{\text {th }}$ day \\
\hline Day 28-60th & Kinetic exercises & ROM - Painless active abduction on $160^{\circ}$ on $35^{\text {th }}$ day \\
\hline
\end{tabular}

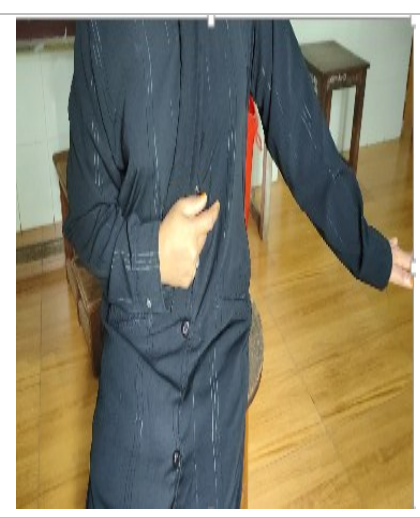

Before treatment

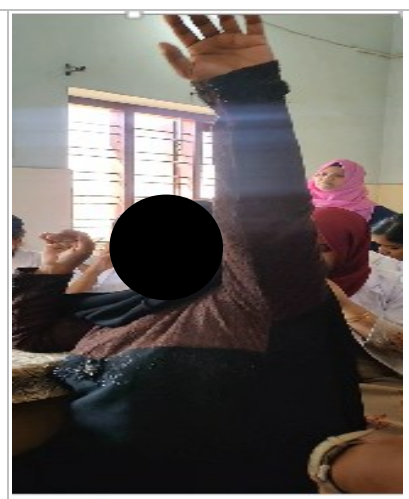

After treatment 


\section{DISCUSSION}

Rotator cuff tear is one of the most commonly seen injuries among workers. The degeneration during old age leading to trivial micro trauma can be considered as a factor that leads to the cuff injury. In the present case, the patient gives a history of recurrent shoulder pain with no limitation in movement of the shoulder joint. A triggering factor of fall lead to the tear of rotator cuff which was weakened previously by degeneration. As the clinical examination and MRI findings revealed that there is small full thickness tear of supraspinatus, severe pain and vascular changes can be expected within the fibres of the cuff. Repetitive micro trauma is an important factor in rotator cuff tendon injury. Tissue irritability, or sensitivity, is the result of these responses and is typically divided into three overlapping stages of inflammation, repair and maturation/ remodelling. One of the reasons for this pain is the exudative and inflammatory changes that take place after the acute injury. This can be explained as Vransopha formed after an Abhighata. The immediate Dushti of Rakta and Pitta can be reduced by Alepana and Bandhana. The Chikitsa Siddhanta of Bhagna is adopted here. Alepana is the immediate management in case of any Sandhimoksha or Bhagna. Susrutacharya has explained that alepana heals Ugra vrana and Shopha when done with appropriate Aushada. ${ }^{5}$ Immobilisation (Bandhana) is the management after Alepana in Vrana sopha. With this we can achieve pain reduction. They reduce further damage of the tissue and limit exudate formation that is a cause for stiffness post traumatically. ${ }^{6}$ In Sashti upakrama of Vrana chikitsa, Rakta visravana is indicated in achira sopha for the removal of Vedana, Paaka. ${ }^{7}$ When explaining about Raktamokshana, Susruthacarya has explained that the Rakta dushti in Pragaada desha is removed by Jaloukavacarana. From the previous studies, it can be explained that the various biologically active substances in the saliva of leeches like hirudin, antithrombin, antitrypsin, antichymotrypsin and so on., help increase microvascularisation through Jaloukavacarana. It has the ability of vasodilatation. ${ }^{8}$ Also, hirudin can reduce synovial inflammation in arthritic patients. ${ }^{9}$ In case of Supraspinatus tear there are chances of complication due to non-healing or poor healing of ruptured tendon because of less blood supply to the critical zone in supraspinatus tendon. Professor Charles Lent, leading biologists of the US said that Leeches are useful in removing the blood from areas where tissue has been transplanted or attached. When blood is accumulated, tissue may die before it heals. Applying of leeches to the area once or twice a day for a week gives the time for the growth of capillaries and thus restores blood circulation. ${ }^{10}$ Biological active substances present in saliva of medicinal leeches can restore blood circulation in the field of inflammation. They help in improving circulation of an organ and provide capillary tissue exchange and, in improving immune protection and regeneration of tissue. The therapeutic effect is not only by letting of blood but also by the secretions which the leech emits into the circulatory system of the patient. ${ }^{11}$ Here, when the shoulder joint was evaluated, it showed an improved AROM (active range of movement) from $40^{\circ}$ to $90^{\circ}$ within 7 days of conservative management. Though repair of supraspinatus tendon was suggested by orthopaedic surgeon, it was not required, and the patient achieved good range of movement after the treatment.

In a supraspinatus tendon tear, there are chances of poor healing because of 'critical zone' in the tendon due to reduced blood supply. If the blood supply is maintained the ruptured tendon may get repaired by itself faster and better. When leeches are applied near to this 'critical zone', due to the presence of antithrombin, antitrypsin and antichymotripsin in the saliva of leech there is improved blood supply as well as reduced inflammation at the rupture site. ${ }^{12}$ The collection of exudates into the capsule around the shoulder joint may lead to stiffness leading to frozen shoulder. Lepam and Upanaham were given to prevent this condition. After three weeks, passive exercises were advised as the pain was reduced. These exercises were useful in preventing disuse atrophy. The loss of muscle strength can be the main reason for reduced movement of the joint.

Once the inflammatory stage is passed with considerable reduction in pain from a VAS 9 to VAS 2, Vatahara chikitsa is adopted to give the muscles good strength. 
The condition can now be correlated to Apabahuka, a type of Vatavyadhi. Apabahuka can be considered as any pathology leading to the loss of movement of baahu. ${ }^{13}$ Two types of Apabahuka are explained; $v=$ Vataja and Vatakaphaja. These may be considered as the two stages of the shoulder impingement syndrome i.e., stage of stiffness and stage of pain.

Here the limitation of movement was seen immediately after trauma (Amsa marmabhigaata) which lead to Stabdha baahuta.

\section{Marmabhighataja Apabahuka \\ Amsa Marmabhigata<smiles>C1=CC=C1</smiles> \\ Vata Prakopa \\ Affliction to Mamsa Sira snayu Asthi \\ Sankocha Bahu Chesta hara

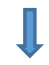 \\ APABAHUKA}

From this Abhighata, Sadhyo vrana is inflicted in the tendon fibres of bahu. The initial Sheeta chikitsa in Sadyo vrana has to be adopted here. Even though Marmabhigata is of Agantuka in nature, in later phases, they result in imbalance of Tridoshas for which the treatments according to the Lakshana has to be given. As Amsa is a Snayu marma, classified as Vaikalyakara marma, the injury to this Marma should not be neglected as it may cause Vikalangata by $B a$ hupraspanditaharatwa. A minimum complication of the Marmabhigata is Stabdha baahuta, which is the lakshana of Apabahuka, so such line of treatment is adopted to prevent Dhatu kshaya which leads to ASmsa sosha (muscle atrophy). Disuse muscle atrophy can be seen if proper rehabilitation is not adopted. The static exercise, followed by isometric and then dynamic exercises are given, especially to the rotator cuffs. Strengthening the other muscles of the upper limb like pectoralis major, latissimus dorsi, deltoid, biceps brachii, and coracobrachialis gives good mobility to the joint and also prevents further injury to the joint.

Passive exercises are valuable for maintaining mobility of the joint. Exercises make stronger ligaments, ten- dons and muscles as well as they improve fluid dynamics and maintain the nutrition in joints. Initially, the range is probably very small. Stretching at this stage is contraindicated. Decreased pain, swelling and muscle guarding are conducive to provide passive exercises.

All these improved the healing process of ruptured tendon and thereby restored its original strength up to the fair extent and achieved a good outcome with conservative management.

\section{CONCLUSION}

Every traumatic injury in a joint is considered as Marmabhigataja vrana and is treated accordingly. The treatment protocol is to minimise further damage and restore the functional mobility. Partial or incomplete rotator cuff tears can be repaired by natural healing process where there is a continuity in the fibres. Return to pre traumatic range of movement is done by strengthening the other intact surrounding muscles. By adopting Vrana chikitsa, Bhagna chikitsa and Vatavyadhi chikitsa in an integrated manner, the best possible results were achieved in this case.

\section{REFERENCES}

1. Murrell GA, Walton JR. Diagnosis of rotator cuff tears. The Lancet. 2001 Mar 10;357(9258):769-70.

2. Solomon L, Warwick DJ, Nayagam S. Apley and solomon's concise system of orthopaedics and trauma. CRC Press; 2014 May 30.

3. Fukuda H. The management of partial-thickness tears of the rotator cuff. The Journal of bone and joint surgery. British volume. 2003 Jan;85(1):3-11.

4. Iannotti JP. Full-thickness rotator cuff tears: factors affecting surgical outcome. JAAOS-Journal of the American Academy of Orthopaedic Surgeons. 1994 Mar $1 ; 2(2): 87-95$

5. Susruta A. Susruta Samhita. Chikitsa sthana 2018;1(14):398.

6. Blom A, Warwick D, Whitehouse M, editors. Apley \& solomon's system of orthopaedics and trauma. CRC Press; 2017 Aug 29.

7. Susruta A. Susruta Samhita. Chikitsa sthana. 2018;1(27):399.

8. Whitaker IS, Cheung CK, Chahal CA, Karoo RO, Gulati A, Foo IT Br J Oral Maxillofac Surg. 2005 Apr; 43(2):155-60.[PubMed] [Ref list]) 
9. Is hirudin a potential therapeutic agent for arthritis?Scott K Ann Rheum Dis. 2002 Jun; 61(6):561-2.

10. Dr. Vasant C. Pati; Principles and practice of Panchakarma; Third editin; Atreya Ayurveda Publication; 2012; Ilkal (Karnataka): 533

11. Dr. Vasant C. Pati; Principles and practice of Panchakarma; Third editin; Atreya Ayurveda Publication; 2012; Ilkal (Karnataka): 538

12. A.M. Abdulkadar, A.M. Ghawi, M. Alaama, M. Awang and A. Merzouk; Leech therapeutic application; Indian Journal of Pharmaceutical Sciences, V. 75/2; March April 2013: 123-137.

13. Nidana sthana, 1/82. Varanasi: Chaukhamba Orientalia; 1991. Sushruta Samhita Dalhana.

\section{Source of Support: Nil \\ Conflict of Interest: None Declared}

How to cite this URL: Bhavya K.G \& George M.J: Rotator Cuff Tendon Injury - An Ayurveda Management With Jaloukavacarana.. International Ayurvedic Medical Journal \{online\} 2021 \{cited June, 2021\} Available from: http://www.iamj.in/posts/images/upload/1293_1298.pdf 